\section{Localization of a gene for Fukuyama type congenital muscular dystrophy to chromosome 9q31-33}

T. Toda, M. Segawa, Y. Nomura, I. Nonaka, K. Masuda, T. Ishihara, M. Sakai, I. Tomita, Y. Origuchi, K. Ohno, N. Misugi, Y. Sasaki, K. Takada, M. Kawai, K. Otani, T. Murakami, K. Saito, Y. Fukuyama, T. Shimizu, I. Kanazawa \& Y. Nakamura

Nature Genetics 5, 283-286 (1993)

The authors wish to correct the name of one of the authors who appeared on this paper,

M. Suzuki should have read M. Sakai.

\section{erratum Somatic and gonadal mosaicism of the Huntington disease gene CAG repeat in brain and sperm}

Håkan Telenius, Berry Kremer, Y. Paul Goldberg, Jane Theilmann, Susan E. Andrew, Jutta Zeisler, Shelin Adam, Cheryl Greenberg, Elizabeth J. Ives, Lorne A. Clarke \& Michael R. Hayden

Nature Genetics 6, 409-413 (1994)

Table 1 was inadvertantly omitted from the final layout of this paper. Table 1 and Fig. 5 appear together below to aid clarity.

\begin{tabular}{cccccc}
\hline \multicolumn{3}{c}{ Table 1 Germ line mosaicism in HD patient } \\
\hline $\begin{array}{c}\text { Donor } \\
\text { age }\end{array}$ & $\begin{array}{c}\text { Onset } \\
\text { age }\end{array}$ & \multicolumn{2}{c}{ HD allele size } & \multicolumn{2}{c}{$\begin{array}{c}\text { Densitometric } \\
\text { (CAG) }\end{array}$} \\
& \multicolumn{2}{c}{$\begin{array}{c}\text { index } \\
\text { Blood }\end{array}$} & Sperm & \multicolumn{2}{c}{ Blood Sperm } \\
70 & 62 & 40 & 40 & 35 & 40 \\
40 & 36 & 42 & 42 & 50 & 66 \\
39 & 31 & 47 & 47 & 65 & 73 \\
31 & 24 & 51 & 51 & 69 & 94 \\
Control & Upper allele size & & \\
28 & N/A & 19 & 19 & 6 & 6 \\
\hline
\end{tabular}
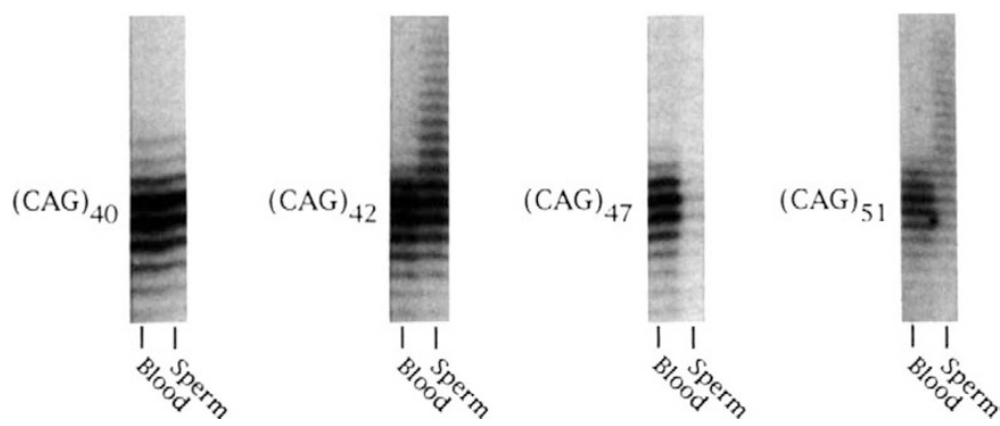

Fig. 5 Comparison of the CAG mosaicism in blood and sperm from four affected individuals. While sperm consistently is more mosaic than blood, there is a trend for increasing mosaicism with larger repeat size (see also Table 1).

\section{A frame shift mutation in the PMP22 gene in hereditary neuropathy with liability to pressure palsies}

G. A. Nicholson, L. J. Valentijn, A. K. Cherryson, M. L. Kennerson, T. L. Bragg, R. M. DeKroon, D. A. Ross, J. D. Pollard, J. G. Mcleod, P. A. Bolhuis \& F. Baas

\section{Nature Genetics 6, 263-266 (1994)}

The authors of this paper wish to correct the stop codon, and define the base numbering used in this paper.

In the first paragraph of the Discussion the third to last and penultimate sentences should now read: All affected family members showed a common PMP22 sequence anomaly which removes a $D d e I$ siteand creates a premature stop codon at base 296 . The mutation causes a frame shift at Ser7 and a nonsense stop coding at codon 36 .

The base numbering used is according to $\mathrm{K}$. Hayasaka et al., Biochem. Biophys. Res. Commun. 186, 827-831 (1992). 